\title{
A multivariate study of the triacylglycerols composition of the subcutaneous adipose tissue of lberian pig in relation to the fattening diet and genotype
}

\author{
By Isabel Viera-Alcaide ${ }^{a}$, Isabel M. Vicario ${ }^{b}$, M.L. Escudero-Gilete ${ }^{b}$, E. Graciani Constante $^{a}$ \\ and Manuel León-Camacho ${ }^{\text {a* }}$
}

\author{
${ }^{a}$ Food Characterization and Quality Department. Instituto de la Grasa (C.S.I.C.). Spain. \\ ${ }^{b}$ Department of Food Science and Nutrition. Faculty of Pharmacy. University of Seville. Spain. \\ ${ }^{*}$ Author to whom correspondence should be addressed \\ Instituto de la Grasa (C.S.I.C.) Avda. Padre García Tejero, 4. \\ 41012 Seville - Spain. \\ Telephone: ++34954611550 - Fax: ++ 34954616790 \\ (e-mail: mleon@cica.es)
}

\section{RESUMEN}

Estudio multivariante de la composición de triglicéridos de la grasa subcutánea del cerdo ibérico en relación con la alimentación y el genotipo.

Se ha determinado la composición de trigliceridos (TGs) en 1560 muestras de grasa subcutánea de cerdo ibérico puro y cruzado (ibericoxDuroc) criados en régimen extensivo en tres sistemas de alimentación: montanera (M), cebo (C) y recebo $(R)$. Diecisiete TGs se han identificado mediante Cromatografía de Gases, y seis de ellos (POO, PSO, POL, $\mathrm{OOO}$, SOO, OOL) representan el $75 \%$. Se encontraron diferencias significativas $(p<0.01)$ para la mayoría de los TGs entre los tres tipos de alimentación. También se investigó el efecto del tiempo de montanera sobre la composición de TGs, encontrándose una correlación positiva $(p<0.05)$ con los siguientes TGs: OOO, SOL, OOL y OLL. Tras 110 días de Montanera, todas las muestras presentaron \% de 000 y OOL por encima del $9.5 \%$ y $4.5 \%$ respectivamente. El genotipo también mostró un efecto significativo $(p<0.01)$ sobre la composición de TGs. Se aplicó Análisis de Componentes Principales y Análisis Lineal Discriminantes a los datos obtenidos. No se obtuvo una buena separación entre los tres grupos de alimentación ( $M, R$ y C), sólo para los grupos de $\mathrm{M}$ y $\mathrm{C}$ se obtuvo una clara separación en base a la composición de TGs.

PALABRAS CLAVE: Ácidos grasos - Cerdo ibérico - Triglicéridos - Análisis multivariante.

\section{SUMMARY}

A multivariate study of the triacylglycerol composition of the subcutaneous adipose tissue of lberian pig in relation to the fattening diet and genotype.

The triacylglycerol (TGs) composition of 1, 560 samples of subcutaneous fat of Iberian purebred and crossbred (iberianxDuroc) pigs reared extensively on three different feeding systems: montanera (M), cebo (C) and recebo (R), were determined. Seventeen TG species were identified by Gas Chromatography and six of them (POO, PSO, POL, OOO, SOO, OOL) accounted for $75 \%$. Significant differences $(p<0.01)$ were found for the majority of TG species among the three types of feeding. The effect of the duration of montanera on the TG composition was also explored and a significant positive correlation $(p<0.05)$ was found with the following TGs: OOO, SOL, OOL and OLL. After 110 days of Montanera, all the samples showed a percentage of $\mathrm{OOO}$ and $\mathrm{OOL}$ over $9.5 \%$ and $4.5 \%$ respectively. Genotype also showed a significant effect $(p<0.01)$ on the TG composition. Principal Component and Linear Discriminant analyses were applied to the data set. No clear separation among the three groups ( $M, R$ and $C$ ) according to the TG profile was achieved. Only $M$ and $C$ groups were clearly separated according to their TG composition.

KEY-WORDS: Iberian pig - Fatty acids - Multivariate analysis - Triacylglycerols.

\section{INTRODUCTION}

The Iberian pig (Sus mediterraneous) is an autochthonous breed grown in Spain, which has survived thanks to the highly valued organoleptic taste of the dry-cured products derived from it (Andersen, Oksbjerg, Young and Therkildsen 2005; Bosi, Cacciavillani, Casini, Lo Fiego and Marchetti, 2000). It is known that the finishing diet of the animals previous to slaughter is one of the main factors affecting the quality of the corresponding dry-cured products (López Bote, 1998). Three different feeding systems can be considered. When the animals are reared outdoors, grazing on acorns (Quercus spp) and pasture, the feeding system is known as 'Montanera' (M). If the animals are fed formulated feed during the final fattening period the system is called "Cebo" (C). An intermediate feeding system is usually called 'Recebo' (R). The highest quality products are those derived from animals grown extensively in montanera and of less quality are the products originated from recebo and cebo animals, respectively. The period in which the animals eat acorn and pasture in montanera, previous to slaughter, varies depending on the resources available in each production zone. However, a minimum period of two months to gain at least $46 \mathrm{Kg}$, is established by law (Boletín Oficial del Estado, 2007). To maintain the high quality 
standard of the Iberian pig products, each designation of origin makes routine inspections to check on the field the fattening diet and rearing system of the animals.

Fatty acid analysis of the subcutaneous fat by gas chromatography is a controversial criterion established for classifying the animals according to the three feeding system. However, the triacylglycerol (TGs) composition of the subcutaneous fat has been poorly studied (Díaz, García-Regueiro, Casillas and De Pedro, 1996; Cava; Ruíz, López-Bote, Marín, García and Ventanas, 1997; Ruíz, Cava, Antequera, Martin, Ventanas and López-Bote, 1998; Tejeda, Gandemer, Antequera, Viau and García, 2002). TG composition has been widely used in oil and fat characterization García-González et al. (2007). In a previous paper León et al. (2007) authors set up a method for analyzing the TG fraction of montanera and cebo subcutaneous fat samples by means of gas chromatography and flame ionization detector concluding that it is possible to discriminate between Montanera and Cebo samples based on two TG molecular species $\mathrm{OOO}$ and PSO.

Another factor which is known to have a significant effect on the quality of meat is genotype. The present knowledge within this area is scattered (Andersen, Oksbjerg and Therkildsen, 2005). Crossbred pigs, mainly lberian x Duroc (IbxDr) pigs are used to improve growth rate and carcass lean content (Lopez Bote, 1998). Studies on the quality traits of biceps femoris and back fat suggest that purebred iberian pigs' tissues are more suitable than crossbred pigs for the production of dry-cured products (Ventanas, Ventanas, Jurado and Estevez, 2006). A genetic effect on the antioxidant, lipolytic and proteolityc activity of pig meat has been suggested (Hernández, Zomeño, Ariño and Blasco, 2004). However, previous studies on Ib and Ibx Dr pigs have shown only a slight effect of genotype on the TG composition of Iberian intramuscular fresh fat Tejeda et al. (2002), but a significant effect on the dry-cured ham (Petron, Muriel, Timon, Martin and Antequera, 2004).

The aim of this work was to study the TG profile of the subcutanous fat of Iberian pigs reared extensively on the three types of fattening diets: Montanera (M), Cebo (C) and Recebo (R). The effect of the genotype and the intensity of the Montanera period on the TG composition were also studied. The final objective was to explore the feasibility of using TG composition for the classification of samples corresponding to the three different fattening systems.

\section{MATERIAL AND METHODS}

\subsection{Animals}

The samples analyzed in this study were representative of 96,863 castrated male Iberian pigs from the designation of origin "Jamón de
Huelva". The samples were taken during four consecutive years (2002 to 2005). The animals were classified into three different groups according to the field notes taken by the veterinary inspector of the Designation of Origin during the final fattening period. All the animals included in the study were reared extensively. One group of animals (39362) was reported to have been reared for a variable period of time (from 50 days to 170 days) in the traditional way, usually called 'montanera' (M) with a fattening diet based exclusively on acorn (Quercus ilex, Q. suber and $Q$. faginea) and pasture. Another group consisted of animals $(14,263)$ fed commercial feed and pasture (extensive fattening system), usually called "cebo" (C) and the last group (43, 238 animals) were animals reared in montanera but including commercial feeds in the final fattening period, which is usually known as "recebo" (R).

\subsection{Samples}

From each sacrificed animal, a sample consisting of a chunk of $3 \times 3 \mathrm{~cm}$ approximately, of at least $6 \mathrm{~mm}$ thick was taken by cutting the rump, at approximately $10 \mathrm{~cm}$ from the tail following the line of the back and containing skin, adipose tissue and some loin. In the laboratory, the skin and the loin were removed (Ministerio de la Presidencia, 2004). All the chunks corresponding to each animal of a lot were punctured and homogenized before extraction. The representative sample of the lot was then obtained by melting the fat in an oven microwave for 3 minutes at $360 \mathrm{~W}$ of power. The representative sample of fat was then filtered and prepared for the analysis. A total of 1, 560 representative samples of Iberian pig fat were analyzed: 652 corresponding to M, 211 corresponding to $\mathrm{C}$ and 697 corresponding to $\mathrm{R}$.

\subsection{TG analysis}

Triacylglycerols were analyzed and identified as described previously by GC Viera Alcaide et al. (2007) in a Varian 3800 (Varian Co, Palo Alto, CA, USA) using a fused silica capillary DB-17HT column $(30 \mathrm{~m} \times 0.25 \mathrm{~mm}$ I.D., $0.15 \mu \mathrm{m}$ film thickness). The oven temperature was kept at $320^{\circ} \mathrm{C}$, and was then raised to $350^{\circ} \mathrm{C}$ at a rate of $2.0^{\circ} \mathrm{C} / \mathrm{min}$ and held isothermally for $10 \mathrm{~min}$. The injector temperature was kept at $360^{\circ} \mathrm{C}$, while the detector temperature was $370^{\circ} \mathrm{C}$. Hydrogen (2.1 $\mathrm{mL} \mathrm{min}^{-1}$ column constant flow) was used as carrier gas, while the make-up gas was nitrogen. A representative chromatogram report of subcutaneous fat and the corresponding peak identification are shown in Figure 1.

\subsection{Statistical analysis}

The Kolmogorov-Smirnov-Lilliefors test was used to evaluate the normality of each variable 


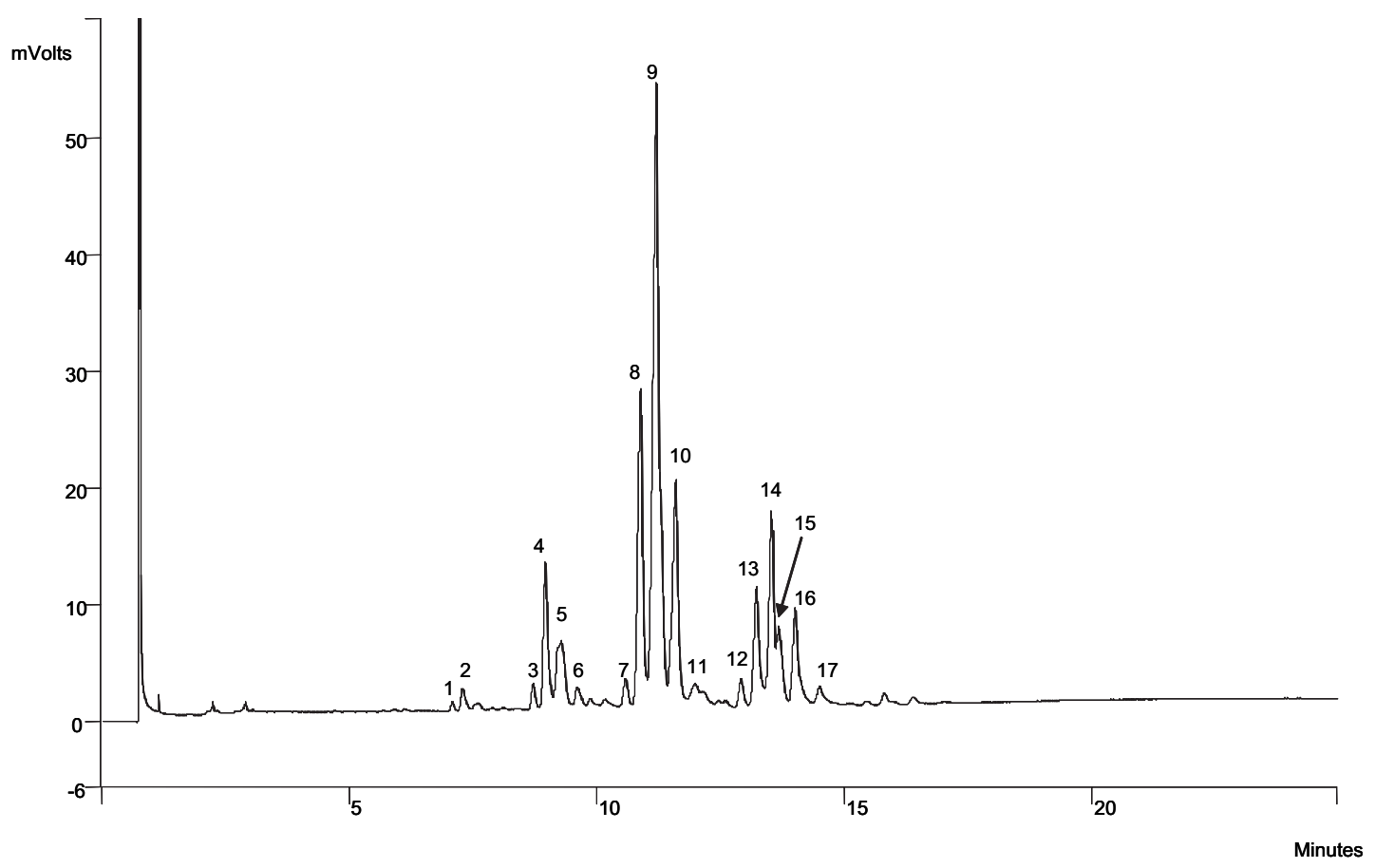

Figure 1

Gas-chromatogram of the triacylglycerols of Iberian pig subcutaneous fat. Labelled peaks identified as: 1: PPP; 2: MOP; 3: PPS; 4: POP; 5: POPo+PLP; 6: PLPo+MLO; 7: PSS; 8: PSO; 9: POO; 10: PLO; 11: PLL+PoLO; 12: SOS; 13: SOO; 14: OOO; 15: SOL; 16: OOL; 17: OLL. (M = Miristic, $\mathrm{P}=$ Palmitic, $\mathrm{Po}=$ Palmitoleic, $\mathrm{S}=$ stearic, $\mathrm{O}=$ Oleic, $\mathrm{L}=$ Linoleic).

included in the study. Since the data distribution was not normal, non parametric tests were applied. The Kruskal-Wallis test was used to find out significant differences for the variables among the three types of feeding groups (M), (R) and (C). This test is considered as an ANOVA test for one factor, called non-parametric ANOVA-1. The MannWhitney $U$ test was used to determinate the differences between fattening diets among the three groups pair by pair (M/C; M/R; C/R) and between genotypes. This test is considered similar to a t-Student test for independent sample groups (StatSoft, 1995).

For classification purposes, Principal Component (PCA) and Linear Discriminant Analyses (LDA) were applied to the triacylglycerol composition to infer differences among groups according to fattening diet and genotype. For the LDA the criterion used for the feature selection of variables included in the model was the forward stepwise approach. The variables were included in the model according to their discriminating power based on the Wilks'l statistic test (StatSoft, 2002). The multivariate statistical analysis was performed by methods of analysis using the software Statistica ${ }^{\circledR} \vee 6.0$ (Statsoft Inc., 2001)

\section{RESULTS AND DISCUSSION}

\subsection{Triacyglycerol profile of adipose tissue}

Seventeen TG molecular species were identified according to their relative retention times to palmitindioleine (Figure 1). Table 1 shows the mean values for the TGs identified corresponding to three consecutive years. Results are shown grouped according to the three fattening diets considered (M, R, C). Six TG species accounted for more than $75 \%$ of total TGs: POO, PSO, PLO, OOO, SOO, and OOL. This profile of TGs is consistent with that reported by Diaz et al. (1996) for fresh ham fat of Iberian pigs also fed on $\mathrm{M}, \mathrm{R}$ and $\mathrm{C}$. The $\%$ of $\mathrm{OOO}$ reported in Diaz et al. (1996) for M animals was slightly higher than the one reported in this study ( $17.7 \%$ vs $11.45 \%)$, probably due to the different analytical methods employed in both studies (high performance liquid chromatography vs GC). Differences observed between data obtained in this study and data reported in bibliography for Iberian pigs TGs (Díaz et al., 1996; Tejeda et al, 2002) could be related to the fact that other studies have been done on a small number of animals under controlled conditions. On the contrary, data reported in this study are representative of a high number of animals grouped according to type of feeding, but under different conditions (amount and time of feeding under the different systems).

In comparison to data reported for TG composition of industrial pigs Davenel et al. (1999), the levels of 000 (from $6.69 \%$ to $11.45 \%$ ) and OOL (from $6.09 \%$ to $3.79 \%$ ) found for the Iberian pig samples analyzed in this study were higher than those found in the adipose tissue of industrial breeds $(3.5 \%$ and $2.6 \%$ respectively). On the contrary, the percentage of PSO found (from 
Table 1

TGs identified in the subcutaneous adipose tissue of Iberian pigs grouped by fattening diet

\begin{tabular}{|c|c|c|c|c|c|c|c|}
\hline TGs & $\begin{array}{l}\text { Montanera } \\
(n=652)\end{array}$ & $\begin{array}{l}\text { Recebo } \\
(n=697)\end{array}$ & $\begin{array}{c}\text { Cebo } \\
(n=211)\end{array}$ & M/R & $M / C$ & $\mathrm{R} / \mathrm{C}$ & $M / R / C$ \\
\hline PPP & $0.18^{a} \pm 0.07$ & $0.20^{b} \pm 0.07$ & $0.29^{c} \pm 0.08$ & ** & ** & ** & ** \\
\hline MOP & $0.70^{a} \pm 0.14$ & $0.75^{\mathrm{b}} \pm 0.16$ & $0.99^{c} \pm 0.17$ & ** & ** & ** & ** \\
\hline PPS & $0.63^{a} \pm 0.16$ & $0.68^{b} \pm 0.18$ & $0.99^{c} \pm 0.22$ & ** & ** & ** & ** \\
\hline POP & $4.88^{a} \pm 0.62$ & $5.20^{b} \pm 0.77$ & $6.72^{c} \pm 0.82$ & ** & ** & ** & ** \\
\hline POPo+PLP & $4.01^{a} \pm 1.00$ & $4.17^{b} \pm 1.11$ & $4.80^{c} \pm 1.25$ & ** & ** & ** & ** \\
\hline PLPO+MLO & $0.78^{a} \pm 0.16$ & $0.79^{a} \pm 0.17$ & $0.85^{b} \pm 0.16$ & ns & $\star \star$ & $\star \star$ & $\star \star$ \\
\hline PSS & $0.89^{a} \pm 0.22$ & $0.95^{b} \pm 0.25$ & $1.41^{c} \pm 0.30$ & ** & ** & ** & ** \\
\hline PSO & $13.31^{\mathrm{a}} \pm 1.51$ & $13.86^{b} \pm 1.72$ & $17.76^{c} \pm 1.59$ & ** & ** & ** & ** \\
\hline POO & $32.43^{a} \pm 2.72$ & $32.37^{a} \pm 2.54$ & $31.53^{b} \pm 3.01$ & ns & ** & ** & ** \\
\hline PLO & $10.25 \pm 0.94$ & $10.31 \pm 0.97$ & $10.28 \pm 0.81$ & ns & ns & ns & ns \\
\hline PLL+PoLO & $1.43^{a} \pm 0.28$ & $1.42^{\mathrm{ab}} \pm 0.28$ & $1.39^{b} \pm 0.28$ & ns & * & ns & ns \\
\hline sos & $1.24^{a} \pm 0.19$ & $1.27^{b} \pm 0.20$ & $1.56^{c} \pm 0.21$ & * & $\star \star$ & ** & ** \\
\hline soo & $6.80^{a} \pm 0.44$ & $6.70^{b} \pm 0.48$ & $6.57^{c} \pm 0.46$ & $\star \star *$ & ** & ** & ** \\
\hline 000 & $11.45^{\mathrm{a}} \pm 1.27$ & $10.68^{b} \pm 1.56$ & $6.69^{c} \pm 0.92$ & $* *$ & $\star *$ & ** & ** \\
\hline SOL & $3.80^{\mathrm{ab}} \pm 0.47$ & $3.81^{a} \pm 0.38$ & $3.73^{b} \pm 0.42$ & ns & ns & * & ns \\
\hline OOL & $6.09^{a} \pm 0.75$ & $5.78^{b} \pm 0.87$ & $3.79^{c} \pm 0.89$ & ** & ** & ** & ** \\
\hline OLL & $1.12^{\mathrm{a}} \pm 0.23$ & $1.06^{b} \pm 0.25$ & $0.66^{c} \pm 0.19$ & ** & ** & ** & ** \\
\hline $\mathrm{SFC}^{20}$ & $11.94^{\mathrm{a}} \pm 1.10$ & $12.35^{\mathrm{b}} \pm 1.26$ & $15.19^{c} \pm 1.16$ & ** & $\star \star$ & ** & $\star \star$ \\
\hline
\end{tabular}

Results are expressed as \% of total TGs analyzed. Values are mean \pm standard deviations.

Means with different letters in the same row are significantly different: ns, not significant, ${ }^{*} p<0.05$, ${ }^{* *} p<0.01$. Significant differences between pairs were obtained by U Mann-Whithne Test. Significant differences for the three types of fattening diet were obtained using the Kruskal Wallis Test.

$13.31 \%$ to $17.76 \%$ ) was lower than that reported for industrial breeds (24.4\%). The solid fat content at $20^{\circ} \mathrm{C}\left(\mathrm{SFC}^{20}\right)$ is a measurement related to the physical properties of fats and PSO has been determined to account for more than $94 \%$ of the variability of this parameter. Davenel et al. (1999) proposed a formula to estimate $\mathrm{SFC}^{20}$ of pig fat based on the PSO content: $S F C^{20}=0.73^{\star} P S O+$ 2.23. When this formula was applied to the data set obtained in this research the mean values obtained for this parameter (Table 1) were also lower than the one reported for industrial breeds $\left(\mathrm{SFC}^{20}=20.1\right)$ (Davenel et al., 1999), which indicates lower melting points for the Iberian pig fat. M samples showed significantly lower $(\mathrm{p}<0.01)$ values than $\mathrm{R}$ and $C$ samples (11.94 $\pm 1.10 \%$; $12.35 \pm 1.26 \%$; $15.19 \pm 1.16 \%)$, respectively. In all cases, SFC ${ }^{20}$ values were lower than $18 \%$, which is the limit for a fat to remain liquid at ambient temperature.

The significant differences found in the TG profiles of the Iberian pig reported as $\mathrm{M}, \mathrm{C}$ and $\mathrm{R}$ are also shown in Table 1. Significant differences $(p<0.01)$ were found among the three types of feeding for all the TGs species analyzed except for PLO. The TG containing two and three saturated fatty acids (PPP, PPS, PSS, MOP, POP, PSO, SOS) showed the highest values (\%) in the animals fed commercial feeds $(\mathrm{C})$, followed by the animals fed a mixed diet (R). The lowest values (\%) were detected in the $\mathrm{M}$ animals. On the contrary, the levels (\%) of diunsaturated and triunsaturated triacyglycerols showed the highest values in $\mathrm{M}$ animals followed by $\mathrm{R}$ and $\mathrm{C}$ respectively. These results are consistent with those reported by Diaz et al. (1996). 


\subsection{Influence of montanera feeding duration on the triacylglycerols composition}

Although a minimum time of two months has been established (BOE, 2007) in montanera for the animals to gain at least $46 \mathrm{Kg}$, the duration of montanera is variable depending on the resources available in each production zone. In this sense we have explored the relationship between the montanera duration (as reported by the veterinary inspector) and the percentage of the different TGs analyzed (only for the $M$ group of animals). A positive and significant correlation $(p<0.05)$ was found between the time in montanera and the following TGs: $\mathrm{OOO}(r=0.34)$ and OOL $(r=0.33)$, which indicates that their TGs increase during montanera time. For the fraction of $\mathrm{OOO}$ and $\mathrm{OOL}$ it was observed (Figure 2) that after 110 days of montanera all the samples showed percentages of $\mathrm{OOO}$ and OOL over 9.5 (Figure 2A) and 4.5 (Figure $2 \mathrm{~B})$ respectively. These results are in agreement with the fatty acid composition of the acorn fruit which is rich in oleic acid (58\%-62\%) and has a significant level of linoleic acid (17\%-22\%) (León, Viera and Vicario, 2004). Díaz et al. (1996), also reported significant differences for $\mathrm{OOO}$ and $\mathrm{OOL}$ between Iberian pigs with different intensities of montanera ( $\mathrm{Kg}$ of acorn ingested by the pig).

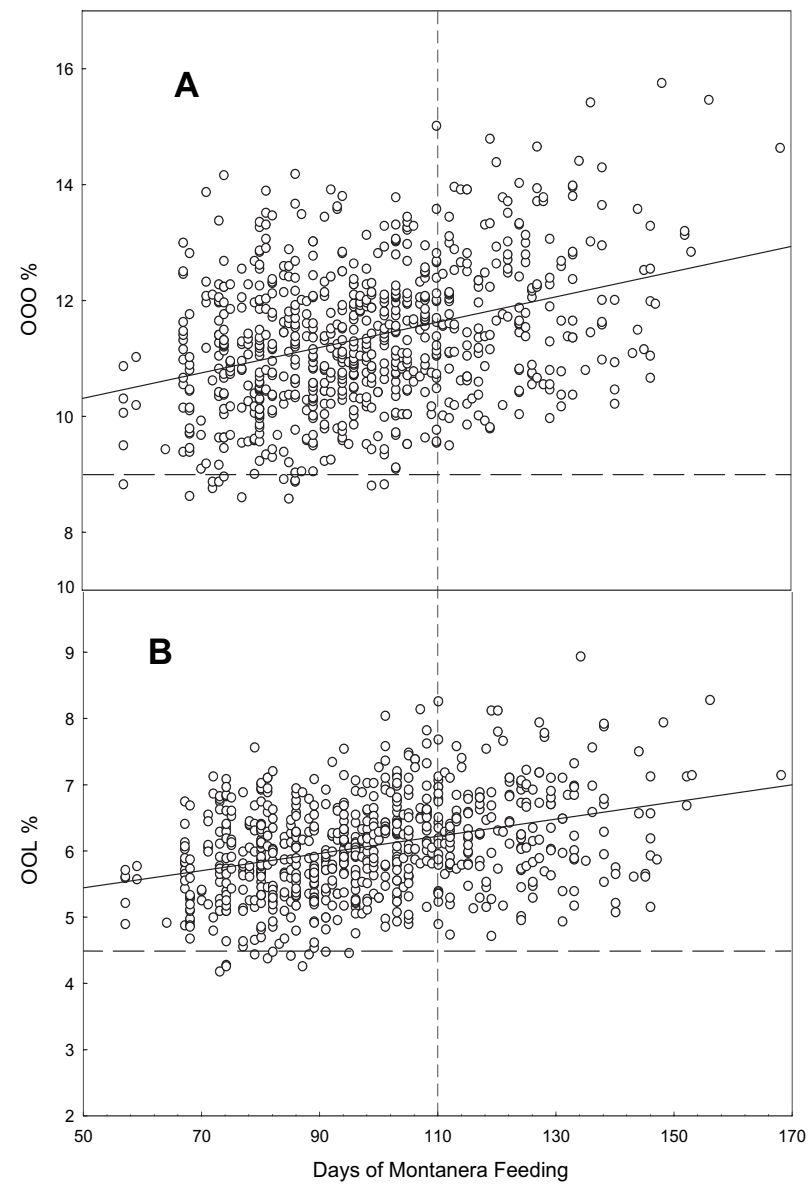

Figure 2

Distribution of the percentages of TGs OOO (A) and OOL (B) during the Montanera feeding time.

\subsection{Genotype and triacylglycerols composition}

Table 2 shows the mean values for the TG species analyzed and the mean $\mathrm{SFC}^{20}$ calculated value, grouped by genotype and fattening diet. Significant differences for the majority of TGs species analyzed were found between purebred $\mathrm{lb}$ and IbxDr animals for each type of fattening diet. The tri and disaturated TG species PPP, PPS, PSS, PSO showed significantly lower $(p<0.01)$ values in purebred than in crossbred pigs for the three types of feeding. On the contrary, significantly higher values in $\mathrm{lb}$ than in $\mathrm{lbxDr}$ pigs were found only for some diunsaturated (SOL) and triunsaturated (OOO, OOL, OLL) TGs. Data reported in the bibliography on the influence of genotype on the TG and fatty acid profile is controversial. While some authors have reported a limited effect of genotype on the TG composition of intramuscular lipids Tejeda et al. (2002), other authors have reported a significantly higher amount of oleic acid in purebred than in crossbred, even for animals fed on the same diet Ventanas et al. (2006). These authors have suggested that these differences could be due to the different activity in $\Delta^{9}$-desaturase enzyme between the different genotypes. In agreement with this, the results obtained in this study indicate that purebred pigs and crossbred pigs, fed on the same diet, show differences which are significant for the majority of the TGs (Table 2). These differences between genotypes are qualitatively more important for animals fed in $\mathrm{M}$, in comparison with animals fed on $\mathrm{R}$ or $\mathrm{C}$ for both groups (Ib and IbxDr). However, diet plays a key role in the TG profile, since for any of the two genotypes studied, the differences between groups of animals under different fattening diets are significant for the majority of the TGs analyzed, these differences being more relevant between $\mathrm{M}$ and $\mathrm{C}$ (Table 3 ). The SFC $^{20}$ values also showed significant differences $(p<0.01)$ among the three fattening diets and between genotypes in each group. The lower values for $\mathrm{SFC}^{20}$ always corresponded to Iberian pigs in any of the feeding systems.

\subsection{Sample classification according to the fattening diet: PCA and LDA analysis}

A preliminary study was conducted based on a PCA analysis which provided an initial evaluation of the discriminating efficiency of the TG variables. Two PCs were extracted explaining up to $63.9 \%$ of the variability. PC1 explained $49.3 \%$ and PC2 explained $14.6 \%$ of the variability. However, a plot of PC1 vs PC2 did not show a clear separation of the three groups according to fattening diet (Figure 3).

In order to achieve a better separation according to the final fattening diet, an LDA was applied to the data set. Classification rules for the samples were calculated as the linear combination of TGs. The classification functions together with $F$ to remove $p$ values for each TG selected are shown in Table 4. The highest discriminating efficiency corresponded 
Table 2

Identified triacylglycerols grouped by fattening diet and genotype

\begin{tabular}{|c|c|c|c|c|c|c|c|c|c|}
\hline \multirow{3}{*}{ TGs } & \multicolumn{3}{|c|}{ Montanera } & \multicolumn{2}{|c|}{ Recebo } & \multicolumn{4}{|c|}{ Cebo } \\
\hline & $100 \%$ & $75 \%$ & \multirow{2}{*}{$\mathbf{P}$} & $100 \%$ & $75 \%$ & \multirow{2}{*}{$\mathbf{p}$} & $100 \%$ & $75 \%$ & \multirow{2}{*}{ p } \\
\hline & $(n=317)$ & $(n=335)$ & & $(n=197)$ & $(n=500)$ & & $(n=102)$ & $(n=109)$ & \\
\hline PPP & $0.18^{\mathrm{a}} \pm 0.08$ & $0.19^{b} \pm 0.06$ & $* \star$ & $0.18^{a} \pm 0.06$ & $0.20^{b} \pm 0.08$ & $\star \star$ & $0.27^{a} \pm 0.08$ & $0.30^{b} \pm 0.08$ & $* *$ \\
\hline MOP & $0.68^{\mathrm{a}} \pm 0.14$ & $0.72^{b} \pm 0.13$ & $\star *$ & $0.73^{a} \pm 0.16$ & $0.76^{b} \pm 0.16$ & $* *$ & $0.98 \pm 0.20$ & $1.01 \pm 0.15$ & ns \\
\hline PPS & $0.60^{\mathrm{a}} \pm 0.15$ & $0.65^{b} \pm 0.16$ & $\star \star *$ & $0.63^{a} \pm 0.17$ & $0.69^{b} \pm 0.18$ & ** & $0.93^{\mathrm{a}} \pm 0.20$ & $1.04^{b} \pm 0.22$ & ** \\
\hline POP & $4.76^{a} \pm 0.62$ & $4.99^{b} \pm 0.60$ & $\star \star *$ & $5.05^{a} \pm 0.75$ & $5.25^{b} \pm 0.76$ & ** & $6.63 \pm 0.86$ & $6.81 \pm 0.78$ & ns \\
\hline $\begin{array}{l}\text { POPO+ } \\
\text { PLP }\end{array}$ & $3.91^{\mathrm{a}} \pm 1.02$ & $0.11^{b} \pm 0.98$ & $\star \star$ & $3.97^{a} \pm 1.21$ & $4.25^{b} \pm 1.05$ & $* *$ & $4.68 \pm 1.42$ & $4.91 \pm 1.05$ & ns \\
\hline $\begin{array}{l}\text { PLPO } \\
+ \text { MLO }\end{array}$ & $0.77 \pm 0.16$ & $0.78 \pm 0.16$ & ns & $0.79 \pm 0.17$ & $0.79 \pm 0.17$ & ns & $0.84 \pm 0.17$ & $0.87 \pm 0.15$ & ns \\
\hline PSS & $0.86^{a} \pm 0.22$ & $0.92^{b} \pm 0.21$ & $\star \star$ & $0.90^{\mathrm{a}} \pm 0.25$ & $0.98^{b} \pm 0.25$ & $* \star$ & $1.33^{a} \pm 0.30$ & $1.48^{b} \pm 0.28$ & $\star \star$ \\
\hline PSO & $13.01^{\mathrm{a}} \pm 1.54$ & $13.58^{\mathrm{b}} \pm 1.42$ & $\star \star$ & $13.52^{\mathrm{a}} \pm 1.78$ & $14.00^{b} \pm 1.68$ & $* \star$ & $17.31^{a} \pm 1.53$ & $18.18^{b} \pm 1.54$ & ** \\
\hline POO & $32.57 \pm 2.60$ & $32.29 \pm 2.83$ & ns & $32.70 \pm 2.83$ & $32.24 \pm 2.40$ & ns & $32.12^{\mathrm{a}} \pm 3.51$ & $30.97^{b} \pm 2.35$ & ** \\
\hline PLO & $10.33^{\mathrm{a}} \pm 0.92$ & $10.18^{\mathrm{b}} \pm 0.96$ & * & $10.30 \pm 1.02$ & $10.31 \pm 0.94$ & ns & $10.43^{a} \pm 0.79$ & $10.14^{b} \pm 0.81$ & ** \\
\hline $\begin{array}{l}\text { PLL } \\
+ \text { POLO }\end{array}$ & $1.47^{\mathrm{a}} \pm 0.27$ & $1.40^{\mathrm{b}} \pm 0.28$ & $\star \star *$ & $1.43 \pm 0.30$ & $1.42 \pm 0.27$ & ns & $1.41 \pm 0.29$ & $1.37 \pm 0.27$ & ns \\
\hline sos & $1.23 \pm 0.20$ & $1.25 \pm 0.19$ & ns & $1.26 \pm 0.21$ & $1.27 \pm 0.19$ & ns & $1.51^{\mathrm{a}} \pm 0.24$ & $1.60^{b} \pm 0.18$ & * \\
\hline SOO & $6.80 \pm 0.42$ & $6.79 \pm 0.47$ & ns & $6.76^{a} \pm 0.50$ & $6.67^{b} \pm 0.47$ & * & $6.56 \pm 0.46$ & $6.58 \pm 0.45$ & ns \\
\hline 000 & $11.55^{\mathrm{a}} \pm 1.22$ & $11.36^{\mathrm{b}} \pm 1.31$ & * & $10.88^{a} \pm 1.50$ & $10.60^{b} \pm 1.57$ & * & $6.74 \pm 0.90$ & $6.64 \pm 0.94$ & ns \\
\hline SOL & $3.89^{\mathrm{a}} \pm 0.51$ & $3.70^{b} \pm 0.40$ & $* *$ & $3.90^{\mathrm{a}} \pm 0.41$ & $3.78^{b} \pm 0.36$ & $* *$ & $3.79^{a} \pm 0.46$ & $3.67^{b} \pm 0.37$ & * \\
\hline OOL & $6.22^{\mathrm{a}} \pm 0.75$ & $5.98^{\mathrm{b}} \pm 0.73$ & $\star \star$ & $5.91^{a} \pm 0.87$ & $5.73^{b} \pm 0.87$ & * & $3.84 \pm 0.99$ & $3.75 \pm 0.78$ & ns \\
\hline OLL & $1.15^{\mathrm{a}} \pm 0.25$ & $1.10^{\mathrm{b}} \pm 0.22$ & $\star \star$ & $1.09^{a} \pm 0.28$ & $1.05^{b} \pm 0.24$ & ns & $0.65 \pm 0.18$ & $0.68 \pm 0.19$ & ns \\
\hline $\mathrm{SFC}^{20}$ & $11.73^{a} \pm 0.25$ & $12.14^{b} \pm 1.03$ & $\star \star$ & $12.10^{\mathrm{a}} \pm 1.30$ & $12.45^{\mathrm{b}} \pm 1.23$ & $\star \star *$ & $14.181^{\mathrm{a}} \pm 1.12$ & $15.50^{\mathrm{b}} 1.2$ & $\star \star$ \\
\hline
\end{tabular}

Results expressed as \% of total TGs analyzed. Values are mean \pm standard deviations. Genotype (100\% or $75 \%)$ Means with different letters in the same row within the same column are significantly different. ns, not significant; ${ }^{*} p<0.05 ;{ }^{* *} p<0.01$. Comparison between genotypes for each feeding regime using the U Mann-Whithney Test. 
Table 3

Significant differences within genotype $(100 \%$ or $75 \%)$ for the TGs analyzed according to fattening diets

\begin{tabular}{lcccccc}
\hline \multirow{2}{*}{ TGs } & \multicolumn{3}{c}{ 100\% Iberian } & \multicolumn{3}{c}{ 75\% lberian xDuroc } \\
\cline { 2 - 6 } & M/R & M/C & R/C & M/R & M/C & R/C \\
\hline PPP & ns & $* *$ & $* *$ & $* *$ & $* *$ & $* *$ \\
MOP & $* *$ & $* *$ & $* *$ & $* *$ & $* *$ & $* *$ \\
PPS & $* *$ & $* *$ & $* *$ & $* *$ & $* *$ & $* *$ \\
POP & $* *$ & $* *$ & $* *$ & $* *$ & $* *$ & $* *$ \\
POPo+PLP & $\mathrm{ns}$ & $* *$ & $* *$ & $* *$ & $* *$ & $* *$ \\
PLPO+MLO & $\mathrm{ns}$ & $* *$ & $* *$ & $\mathrm{~ns}$ & $* *$ & $* *$ \\
PSS & $*$ & $* *$ & $* *$ & $* *$ & $* *$ & $* *$ \\
PSO & $* *$ & $* *$ & $* *$ & $* *$ & $* *$ & $* *$ \\
POO & $\mathrm{ns}$ & $* *$ & $* *$ & $\mathrm{~ns}$ & $* *$ & $* *$ \\
PLO & $\mathrm{ns}$ & $\mathrm{ns}$ & $\mathrm{ns}$ & $*$ & $\mathrm{~ns}$ & $*$ \\
PLL+PoLO & $*$ & $\mathrm{~ns}$ & $\mathrm{~ns}$ & $\mathrm{~ns}$ & $\mathrm{~ns}$ & $*$ \\
SOS & $\mathrm{ns}$ & $* *$ & $* *$ & $\mathrm{~ns}$ & $* *$ & $* *$ \\
SOO & $\mathrm{ns}$ & $* *$ & $* *$ & $* *$ & $* *$ & $\mathrm{~ns}$ \\
OOO & $* *$ & $* *$ & $* *$ & $* *$ & $* *$ & $* *$ \\
SOL & $\mathrm{ns}$ & $\mathrm{ns}$ & $\mathrm{ns}$ & $* *$ & $\mathrm{~ns}$ & $* *$ \\
OOL & $* *$ & $* *$ & $* *$ & $* *$ & $* *$ & $* *$ \\
OLL & $* *$ & $* *$ & $* *$ & $* *$ & $* *$ & $* *$ \\
\hline
\end{tabular}

ns, not significant; * $p<0.05 ;{ }^{* *} p<0.01$. Comparison between fattening diets using the U Mann-Whithney Test.

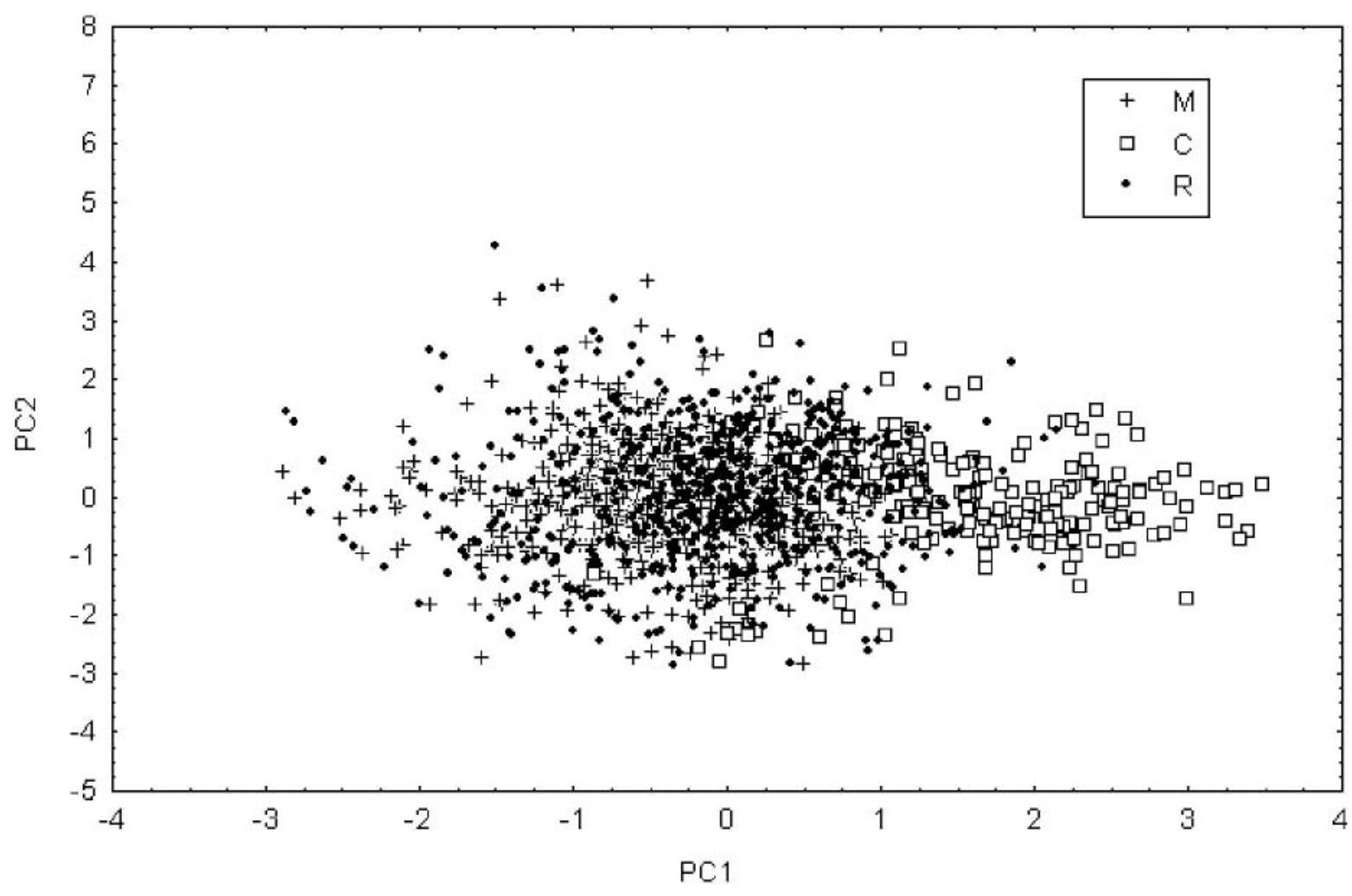

Figure 3

Projection of Montanera (M), Recebo (R) and Cebo (C) samples onto the space defined by PC1 and PC2. 
Table 4

Results of the stepwise discriminant function analysis considering the "fattening diet" as grouping factor and a priori classification probabilities the same for all groups

\begin{tabular}{|c|c|c|c|c|c|}
\hline TGs & $\begin{array}{c}M \\
p=0.33333\end{array}$ & $\begin{array}{c}C \\
p=0.33333\end{array}$ & $\begin{array}{c}R \\
p=0.33333\end{array}$ & $\begin{array}{c}F \text { to remove } \\
(2.1546)\end{array}$ & p-Level \\
\hline 000 & 49.425 & 47.690 & 49.210 & 27.70038 & 0.00000 \\
\hline SOO & -11.141 & -10.911 & -11.272 & 0.64430 & 0.525169 \\
\hline PPS & -278.444 & -294.201 & -282.534 & 22.03277 & 0.000000 \\
\hline PSO & 37.647 & 38.462 & 37.751 & 8.05380 & 0.000331 \\
\hline POP & 144.303 & 147.697 & 145.756 & 18.46984 & 0.000000 \\
\hline PSS & 53.125 & 58.012 & 54.258 & 10.08771 & 0.000044 \\
\hline MOP & -128.180 & -134.994 & -129.820 & 7.43042 & 0.000614 \\
\hline SOL & 81.453 & 82.838 & 81.835 & 5.04515 & 0.006547 \\
\hline OOL & 33.001 & 32.317 & 33.124 & 4.18650 & 0.015372 \\
\hline PPP & -123.131 & -127.715 & -125.812 & 2.85440 & 0.057894 \\
\hline Constant & -983.097 & -989.117 & -987.440 & & \\
\hline
\end{tabular}

to OOO followed by PPS and POP. The highest percentage of predicted correct classification (Table 5) was obtained for C samples (99.5\%). However the number of misclassified samples increased in the $\mathrm{M}$ and $\mathrm{R}$ groups (only $63.3 \%$ and $53.9 \%$ of corrected classified samples respectively). $39 \%$ of $\mathrm{R}$ samples were misclassified as $\mathrm{M}$ and $7 \%$ as $\mathrm{C}$. Also, $37 \%$ of $\mathrm{M}$ samples were misclassified as $\mathrm{R}$ and only $0.3 \%$ as $\mathrm{C}$. This is a foreseeable result since the $R$ animals received a mixed diet which included acorns and pasture and a variable amount of concentrated feed, so their TG profile resembles

Table 5

Classification Matrix corresponding to the stepwise discriminat analysis. Rows indicate observed classifications and columns the predicted classifications. A priori classification probabilities are the same for all groups

\begin{tabular}{lrrrr}
\hline & $\begin{array}{c}\text { Correct } \\
\text { M }\end{array}$ & \multicolumn{1}{l}{ M } & \multicolumn{1}{l}{ C } & \multicolumn{1}{l}{ R } \\
\hline C & 63.3 & 413 & 2 & 237 \\
R & 99.5 & 0 & 210 & 1 \\
Total & 53.9 & 272 & 49 & 376 \\
\hline
\end{tabular}

that of the $M$ group more than the $C$ group. According to this it is not feasible to use the TGS profile to discriminate between $\mathrm{M}$ and $\mathrm{R}$ samples. However, it is possible to achieve a clear separation between $\mathrm{M}$ and $\mathrm{C}$ groups carrying out a new LDA, in which the information referring to the $R$ group has been omitted, as is shown in Figure 4.

\section{CONCLUSIONS}

According to the results obtained in this study, the TG composition of the subcutaneous adipose tissue of the Iberian pig is affected by genotype and feeding system. The duration of montanera has a positive correlation with some TG species containing oleic acid (OOO; OOL; SOL; OLL). Consequently, levels over $9.5 \%$ of $\mathrm{OOO}$ and $4.5 \%$ of OOL are always found in animals fed at least 110 days in montanera. The TG composition can discriminate between animals of $\mathrm{M}$ and $\mathrm{C}$ feeding systems, but is not a good parameter to discriminate between $\mathrm{M}$ and $\mathrm{R}$.

\section{ACKNOWLEDGEMENTS}

The authors are grateful to the Designation of Origin "Jamón de Huelva" especially to Mr. J. de Mier for the collaboration and help given and Ms. E. Olivera for the technical assistance. 


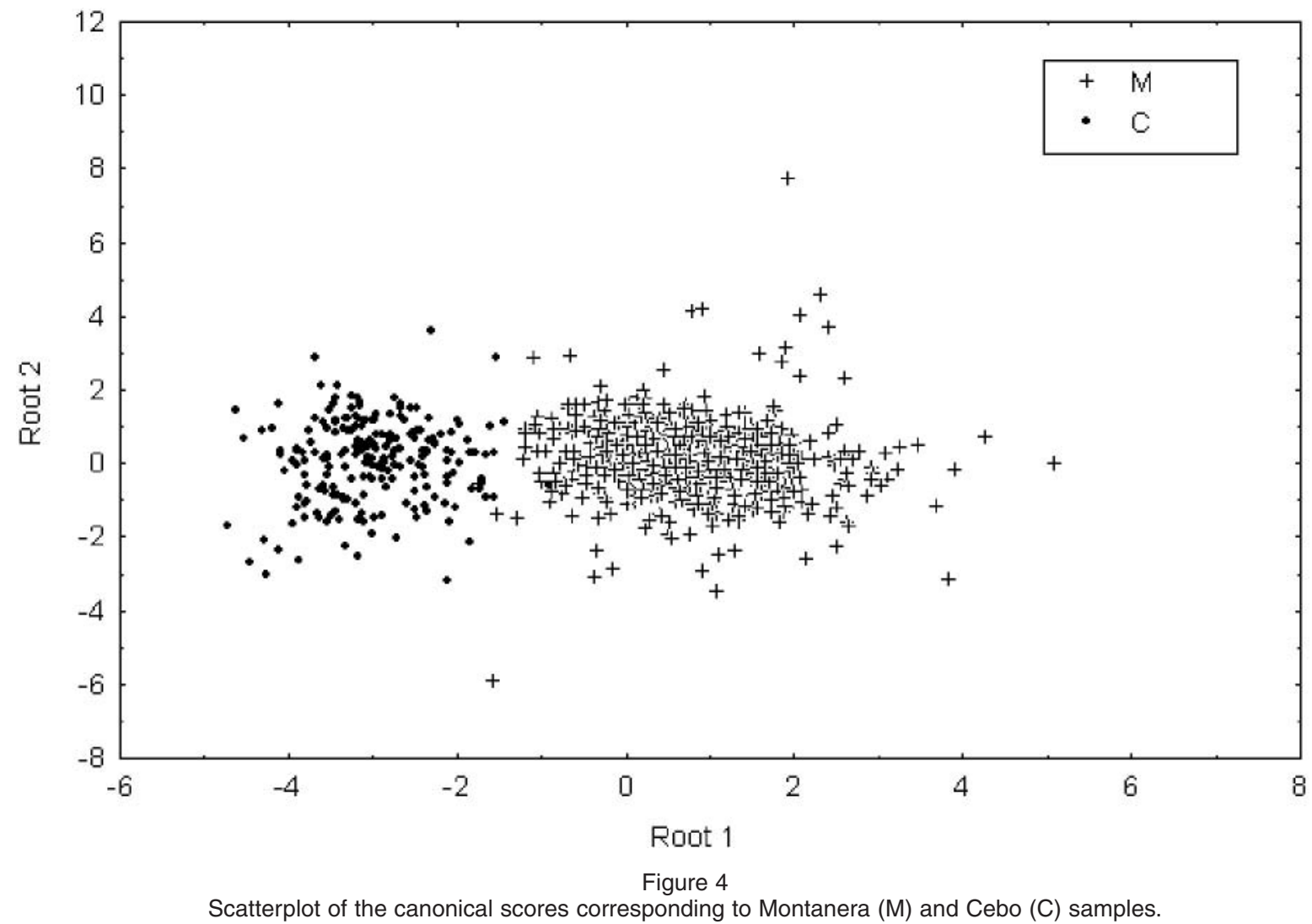

\section{REFERENCES}

Andersen HJ, Oksbjerg N, Therkildsen M. 2005. Potencial quality control tools in the production of fresh pork, beef and lamb demanded by the European society. Livestock Production Scien. 94, 105-124.

Andersen HJ, Oksbjerg N, Young JF, Therkildsen M. 2005. Feeding and meat quality- a future approach. Meat Sc, 70, 543-554.

Bénédicte L, Guillard A. 2005. Outdoor rearing of cull sows: Effects on carcass, tissue composition and meat quality. Meat Sci. 70, 247-257.

Boletín Oficial del Estado (BOE) (2004). Orden PRE/3844/2004.Por la que se establecen los métodos oficiales de toma de muestras en canales de cerdos ibéricos y el método de análisis para la determinación de la composición de ácidos grasos de los lípidos totales del tejido adiposo subcutáneo de cerdos ibéricos. (pp. 38770-38775). Madrid, Spain.

Boletín Oficial del Estado (BOE) 2007. Real Decreto 1469/2007 por el que se aprueba la norma de calidad para la carne, el jamón, la paleta y la caña de lomo ibéricos (pp. 4508745104). Madrid, Spain.

Bosi P. Cacciavillani JA, Casini L, Lo Fiego DP, Marchetti M. 2000. Effects of dietary high-oleic acid sunflower oil, Koper and vitamin E levels on the fatty acid composition and the quality of dry cured Parma ham. Meat Sci, 54, 119-126.

Cava R, Ruíz J, López Bote C, Marín L, García C, Ventanas J. 1997. Influence of finishing diets on fatty acid profiles of intramuscular lipids, triacylglycerol and phospolipids in muscles of the lberian pig. Meat Sci. 45, 263-270.

Davenel A, Riaublanc A, Marchal P, Gandemer G. 1999. Quality of pig adipose tissue: relationship between solid fat content and lipid composition. Meat Sci. 51, 73-79.

Díaz I, García Regueiro JA, Casillas M. De Pedro E. 1996. Triglyceride composition of fresh fat from Iberian pigs produced with different systems of animals nutrition. Food Chem, 55, 383-387.

García-González DL, Viera M, Tena N, Aparicio R. 2007. Evaluation of the methods based on triglycerides and sterols for the detection of hazelnut oil in olive oil. Grasas Aceites 58 (4), 344-350.

Hernández P, Zomeño L, Ariño B, Blasco A. 2004. Antioxidant, lipolytic enzyme activities in pork meat from different genotypes. Meat Sci, 66, 525-529.

Larsson K. (1986). Physical properties-structural and physical characteristics. In F.D. Gustone, J.L.Hawood \& P.B. Padley Eds., The Lipid Handbook, London (UK); Chapman and Hall.

León M, Viera I, Vicario IM. 2004. Acorn (Quercus spp.) Fruit lipids: Saponificable and Unsaponificable fractions: a detail study. JAOCS 81, 447-453.

Lopez Bote CJ. 1998. Sustained utilization of the iberian pig breed. Meat Sci. 49 (suppl) S17-S27.

Perona JS, Ruiz-Gutierrez V. 2005. Quantitative lipid composition of Iberian pig muscle and adipose tissue by HPLC. Journal of Liquid 
Chromatography \& Related Technologies 28 (15) 2445-2457.

Petron MJ, Muriel E, Timon ML, Martin L, Antequera T. 2004. Fatty acids and triacylglycerols profiles from different types of Iberian dry-cured hams. Meat Sci. 68 (1) 71-77

Rey Al, Daza A, Lopez-Carrasco C, Lopez-Bote CJ. 2006. Feeding Iberian pigs with acorns and grass in either free-range or confinement affects the carcass characteristics and fatty acids and tocopherols accumulation in Longissimus dorsi muscle and backfat. Meat Sci, 73 (1) 66-74.

Ruíz J, Cava R, Antequera T, Martin L, Ventanass J, López-Bote C J. 1998. Prediction of the feeding back-ground of Iberian pigs using the fatty acid profile of subcutaneous, muscle and hepatic fat. Meat Sci, 49, 155-163.

StatSoft Inc. 1995. Statistica 5.5 for Windows Computer Program, Tulsa, OK. StatSoft, Inc., 2300 East 14th Street,Tulsa, OK 74104.

StatSoft Inc. 2001. Statistica for Windows v.6.0. Data analysis software system, Tulsa, Oklahoma.
StatSoft, Inc. 2002. Electronic Statistics Textbook. Tulsa, OK: StatSoft. Available at: http://www.statsoft.com/textbook/stathome.html

Tejeda JF, Gandemer G, Antequera T, Viau M, García C. 2002. Lipid traits of muscles as related to genotype and fattening diet in Iberian pigs: total intramuscular lipids and triacylglycerols. Meat Sci, 60, 357-36

Ventanas S, Ventanas J, Jurado A, Estevez M. 2006. Quality traits in muscle biceps femoris and back-fat from purebred Iberian and reciprocal Iberian x Duroc crossbred pigs. Meat Sci. 73 (4) 651-659.

Viera-Alcaide I, Vicario IM, Graciani-Constante E, León-Camacho M. 2007. Authentication of fattening diet of Iberian pig according to their triacylglycerols profile from subcutaneous fat. Anal. Chim. Acta 596, 319-324.

Recibido: $15 / 2 / 08$ Aceptado: 18/3/08 